\title{
Vector Error Correction Analysis of Foreign Direct Investment and its Effect on the Performance of Nigerian Economy (1990- 2018)
}

\author{
Andabai Priye WerigbeleghaPhD ${ }^{1^{*}}$, Mary Ann Nwamaka IgbodikaPhD ${ }^{2}$ \\ ${ }^{I}$ Department of Banking and Finance, Niger Delta University, Bayelsa State \\ ${ }^{2}$ Department of banking and Finance, Chukwuemaka Odumegwu Ojukwu University, Igbariam Campus, \\ Anambra State
}

*Corresponding Author: Andabai, Priye Werigbelegha, Department of Banking and Finance, Niger Delta University, Bayelsa State

\begin{abstract}
The study evaluated the Vector Error Correction analysis of foreign direct (FDI) investment and its effect on the performance of Nigerian economy; for the period 1990-2018. Secondary data were used and collected from Central Bank of Nigeria Statistical Bulletin. The study used Gross Domestic Product as the dependent variable to measure economic performance; whereas, Exchange Rate, Foreign Direct Investment and Inflation Rate respectively were employed as the explanatory variables. The result confirmed that about 78\% short-run adjustment speed from long-run disequilibrium. The study revealed that foreign direct investment had a significant effect on Gross Domestic Product in Nigeria. Exchange rate was positive; but had an insignificant effect on Gross Domestic Product in Nigeria. Inflation rate had an insignificant effect on Gross Domestic Product. The coefficient of determination indicated that about $64 \%$ of the variations in economic growth can be explained by changes in foreign direct investment variables in Nigeria. The study concluded that foreign direct investment had significantly affected the growth and development of the Nigerian economy. The study recommended that the Government and policy makers should provide adequate infrastructure and policy framework that will be conducive for doing business in Nigeria, so as to attract inflow of FDI. The policy makers and government should formulate policies that will be favorable to local investors in order to complement the inflow of investments from abroad. Government should improve the investment climate in order to encourage domestic and foreign investors through infrastructure development.
\end{abstract}

Keywords: VECM Analysis, Foreign Direct Investment, Economic, Performance, Nigeria.

\section{INTRODUCTION}

Nigeria as one of the developing countries of the world has adapted a number of strategies aimed at accelerating growth and development of the domestic economy; thus, one of such is to attract foreign direct investment (FDI) into the country. Study by Andabai and Igbodika (2018) posited that in a globalized world no country is self-sufficient, indeed economies all over the world are expected to linked directly or indirectly together. Thus, this relationship is also made possible through foreign direct investment. The work of Uguegbe (2017) viewed foreign direct investment as a catalyst for growth and development in any modern economy; because, it stimulates domestic investment through increase in capital formation and facilitating technology transfer in the host countries. Hence, as a result, foreign direct investment has been considered as one of the most important sources of external inflow to the Nigerian economy over the years (Legbosi, 2017). The work of Ogbeke (2018) revealed some potential advantages of the foreign direct investment to the host economy as: to facilitates the utilization and exploitation of local raw material, introduces modern techniques of management and marketing, eases the access to new technologies, foreign direct investment inflow can be used for financing current account deficit etc. Study by Togbuko(2018) stated that government have been trying to lift the country out of the economic doldrums without achieving success as desired. One of the major constraint identified by the work of Ogbekondu (2018) is inadequate savings needed for the required investment. Hence, foreign direct investment is needed to reduce the difference between the desired gross domestic investments and domestic savings in an economy. 
The work of Jehu and Ogubunka (2018) stressed that foreign direct investments include: mergers and acquisitions, building new facilities, reinvesting profits earned from overseas operations and intra company loans. Empirical study by Legbosi (2017) revealed that foreign direct investment aids the inflow of technology and skills and fills the gap between domestically available supplies of savings, foreign exchange and government revenue. The study conducted Udoh and Egwaikhide (2016)stated that the major FDI inflow into the country goes to the oil sector of the economy; which appears to undermining the relevance of investing in the non-oil sector, leaving the economy in a mono-cultural and import dependent nation. Hence, prior to the discovery of oil in commercial quantity in Nigeria, the non-oil sector such as the agricultural and the manufacturing sector were the pillar of Nigerian economy and accounted for about $90 \%$ of foreign earnings in the economy(Andabai \& Ikeora, 2018). This explained the huge inflow of foreign direct investment into the sectors that gave rise to some manufacturing firms such as Coca-Cola, UAC and Leventis etc. Hence, the neglect of the real sector occasioned by the oil boom led to the huge inflow of foreign direct investment to the oil sector at the expense of the non-oil sector in Nigeria. Thus, the importance of the non-oil sector cannot be over emphasized in achieving growth and development of any modern economy.

\section{THEORETICAL FRAMEWORK}

The theoretical framework of this study is predicated on the foreign direct investment theory. The theory plays a significant role in the international economy. In the second world most of the investments were of portfolio; and as at that period, about $90 \%$ of British investments were in France and Germany. Exchange then were negligible and political situation were stable, these international portfolio investments were governed by interest rate differential. Hence, a distinct feature of direct investment is that investors wants to control over the investments. The work of Buchi and Kolunbo (2018) posited that one of the main determinants of FDI is technological superiority or superior managerial skills. A firm under monopolistic or oligopolistic market condition may develop some new product or new product technology it wants to make use of its innovation to increase its possibility of making profit from its superior technology. Therefore, it may be decided on entering a foreign market, the way to do this is by way of foreign direct investment. However, Basu and Srinivasan (2017) posited that the activities of FDI are often two sided operations, for example, U.S.A can make direct investment in Europe; while, Western Europe can also make direct investment in USA. Though United States seems to have the most developed technology, because, the country has the most developed technology in all sectors of the economy. For example, German and Swedish industrial technology are also sophisticated compare to the American counterpart. This had made German and Swedish industries to engage in direct investment in the United States. This is an improvement in balance of payment on the long run. However, the effect could be negative from a real point of view; the effect could also be beneficial as long as the positive effect on economic growth. The adverse effect of host country FDI is that it may stifle scientific research and development work in the host country. It also could lead to exploitation especially for less developed countries (Markusen \& Venables, 2018).

\subsection{Empirical Review}

Asiedo (2003) used panel data for 22 countries in sub-Saharan African over the period of 1984-2000 to examine the impact of political risk, institutional framework and government policy on the FDI inflows. The dependent variable was the rate of FDI net flows to GDP while the independent variable used include: natural resource intensity, attractiveness of the host country's market, infrastructural development, macro-economic instability, openness to FDI, host country institution and political instability. The results showed that macro-economic stability, efficient institution, political stability and goods regulatory framework have positive impacts on FDI.

Ayanwale (2017) investigated the empirical relationship between non-extractive FDI and economic growth in Nigeria. Using OLS estimates, the study found that FDI led growth for Nigeria, Sri Lanka, Tunisia, and Egypt; and based on weak erogeneity tests, a long run causality between FDI and economic growth running in both directions was found for the same set of countries. Johansen cointegration framework and a multivariate VAR within a vector error correction model, found evidence of long- run equilibrium relationship between economic growth. Buchi and Kolunbo (2018) used cointegration analysis and a Vector Error Correction (VEC) models to examine the relationship between 
Foreign Direct Investment (FDI) and economic growth in Nigeria. The results show that FDI inflows play a pivotal role in determining the short and long-run movement of economic growth through capital accumulation. However, a FDI inflow was found to have a negative effect on the economy.

Akunde (2017) examined the impact of real exchange rate on the growth of non-oil export in Nigeria. The study showed the effect of real exchange rate misalignment and volatility on the growth of nonoil exports. The study observed that irrespective of the alternative measures of misalignment employed, both real exchange misalignment and volatility adversely affected growth of non-oil exports. Eme and Johnson (2012) investigated the effect of exchange rate movements on real output growth in Nigeria for the period of 1986-2010. The result revealed that there is no evidence of a strong direct relationship between changes in exchange rate and output growth. Rather, Nigeria economic growth has been directly affected by monetary variables.

Udoh and Egwaikhide (2016) examined exchange rate volatility, inflation uncertainty and foreign and foreign direct investment in Nigeria from 1980-2015 using the GARCH model. The study found that RGDP, trade openness is positively related to FDI inflow while inflation uncertainty, exchange rate volatility, government consumption expenditure, political instability, domestic credit to private sector and foreign interest rate are negatively related to FDI inflow to Nigeria.

\section{Methodology}

The study employed ex-post-facto research design. Secondary data were used and collected from Central Bank of Nigeria Statistical Bulletin. The study used Gross Domestic Product as the dependent variable to measure economic Growth; whereas, Exchange Rate, Foreign Direct Investment and Inflation Rate.

\subsection{Model Specification}

Multivariate linear regression model is used to test the hypotheses proposed for this study. Based on this, a model is adapted from the study carried out by (Jehu \& Ogubunka, 2018)). The model is stated as: $\mathrm{GDP}=f(\mathrm{FDI}, \mathrm{EXR})$. Where: GDP $=$ Gross Domestic Product as proxy for Economic Growth. EXR = Exchange Rate. The above model is modified in this study by introducing inflation rate and was employed as independent variable. Hence, the modified model was stated as: GDP $=f(\mathrm{FDI}$, EXR, INF).

The econometric model is stated as:

$\mathrm{Ln}(\mathrm{GDP})=\mathrm{a}_{0}+\mathrm{Lna}_{1} \mathrm{FDI}+\mathrm{Lna}_{2} \mathrm{EXR}+\mathrm{Lna}_{3} \mathrm{INF}+\mu$

Where: GDP $=$ Gross Domestic Product, FDI $=$ Foreign Direct Investment

$E X R=$ Exchange Rate, INF $=$ Inflation $._{0^{-}} \mathrm{a}_{3}=$ constant parameters, $\mu=$ the error term, $\mathrm{a}_{0}=$ intercept and $a_{1}, a_{2}$ and $a_{3}$ are the coefficients of the regression equation. $\mu$ is the stochastic or error term; while, $\mathrm{Ln}$ is the natural $\log$ of the variables. Log transformation is necessary to reduce the problem of heteroskedasticity; because, it compresses the scale in which the variables are measured, thereby reducing a tenfold difference between two values to a twofold difference (Gujarati, 2004).

\section{Data Presentation ANd Discussion}

The study centered on the effect of foreign direct investment on the performance of Nigerian economy; for the period 1990-2018. The study used Gross Domestic Product. as the dependent variable to measure economic Growth; whereas, Exchange Rate, Foreign Direct Investment and Inflation Rate respectively as the explanatory variables. respectively as indicated in appendix $\mathbf{1}$.

Table1: Descriptive statistics

\begin{tabular}{|l|l|l|l|l|}
\hline & GDP & FDI & EXR & INFR \\
\hline Mean & 64868.39 & 54734.94 & 12.36450 & 27.25363 \\
\hline Median & 33728.98 & 34856.45 & 16.86500 & 27.14370 \\
\hline Maximum & 67953.76 & 72469.30 & 36.09000 & 45.10000 \\
\hline Minimum & 25433.64 & 34337.59 & 9.250000 & 23.10000 \\
\hline Std. Dev. & 6.113602 & 148.6905 & 5.409579 & 9.617132 \\
\hline Skewness & 0.278525 & 3.111248 & 1.067069 & 0.175686 \\
\hline Kurtosis & 3.075432 & 14.12640 & 5.256220 & 2.604247 \\
\hline
\end{tabular}


Vector Error Correction Analysis of Foreign Direct Investment and its Effect on the Performance of Nigerian Economy (1990-2018)

\begin{tabular}{|l|l|l|l|l|}
\hline & & & & \\
\hline Jarque-Bera & 0.372435 & 203.26433 & 12.36482 & 0.253744 \\
\hline Probability & 0.776995 & 0.000000 & 0.003627 & 0.751799 \\
\hline & & & & \\
\hline Sum & 162.3100 & 3173.310 & 596.4000 & 1486.929 \\
\hline Sum Sq. Dev. & 1100.357 & 685374.4 & 907.1700 & 2835.166 \\
\hline & & & & 29 \\
\hline Observations & 29 & 29 & 29 & 29 \\
\hline & & & & \\
\hline
\end{tabular}

Source: Author's computation with the use of E-view 9.1

The descriptive statistics on table 1 shows that Gross Domestic Product for the period under study had a mean value of \$64,868,Foreign Direct Investment had \$54,734 and Exchange Rate had 12.36\%; while, inflation rate had $27.25 \%$. The Jarque-Bera statistic shows that two of the variables, namely Gross Domestic Product and Foreign Direct Investment were normally distributed while Foreign Direct Investment and Exchange Rate were highly skewed. Hence, Gross Domestic Product has a mean of $\$ 64,868$ this implies that for the period under review the Gross Domestic Product was very high. This is because, foreign direct investment had significantly affected the growth and development of the Nigerian economy.

\subsection{Unit Root Test}

The stationary test of the variables was done using the Augmented Dicker Fuller (ADF) Unit Root Test. The result on table 2 shows that all the variables are integrated at first difference i.e. 1(1) at the $5 \%$ or $1 \%$ level of significance.

Table2: Unit Root Tests Analysis

\begin{tabular}{|l|l|l|l|l|}
\hline Variables & ADF test Statistics & Mackinnon critical vale @ 5\% & No of the time difference & Remark \\
\hline GDP & 6.8564732 & -8.735463 & I (1) & Stationary \\
FDI & -3.9467385 & -6.846578 & I(1) & Stationary \\
EXR & -6.8493033 & -3.756453 & I $(1)$ & Stationary \\
INF & 3.7498565 & 6.856473 & I $(1)$ & Stationary \\
\hline
\end{tabular}

Notes: (1) $1 \%$ level of significance, $5 \%$ level of significance, $10 \%$ level of significance. The tests accepted at $5 \%$ level of significance. Source: Researcher's Estimation using- E-views 9.1

\subsection{Test for Co-Integration}

Hence, having found that all the variables are stationary at first difference, the next step is to perform Johansen co-integration procedure to ascertain whether Gross Domestic Product (GDP), Foreign Direct Investment (FDI), Exchange Rate (EXR) and Inflation Rate (INF) are co-integrated in the same order. The results of the test are presented on table 3.

Table3: Multivariate Johansen's Co-Integration Test Result

\begin{tabular}{|l|l|l|l|l|l|l|}
\hline $\begin{array}{l}\text { Null } \\
\text { hypotheses }\end{array}$ & $\begin{array}{l}\text { Alternative } \\
\text { hypotheses }\end{array}$ & Eigen value & $\begin{array}{l}\text { Likelihood } \\
\text { ratio }\end{array}$ & $\begin{array}{l}\text { Critical vales } \\
5 \%\end{array}$ & $\begin{array}{l}\text { Critical value } \\
1 \%\end{array}$ & $\begin{array}{l}\text { Hypothesized } \\
\text { No. of CE(s) }\end{array}$ \\
\hline $\mathrm{r}=0$ & $\mathrm{r}=1$ & 0.853686 & 68.83546 & 58.26 & 46.08 & None \\
\hline $\mathrm{rd} \leq 1$ & $\mathrm{r}=2$ & 0.735409 & 52.86453 & 48.65 & 34.53 & At most 1 \\
\hline $\mathrm{rd} \leq 2$ & $\mathrm{r}=3$ & 0.635735 & 48.25387 & 34.87 & 28.13 & At most 2 \\
\hline $\mathrm{rd} \leq 3$ & $\mathrm{r}=4$ & 0.563783 & 34.86473 & 28.25 & 24.87 & At most 3 \\
\hline
\end{tabular}

Source: E-views Econometrics 9.1, Note*(**) denotes rejection of hypothesis at $5 \%(1 \%)$ significance level.

\subsection{Vector Error Correction Model}

The Error Correction coefficient contains information about whether the past values affect the current values of the variable under study and the significant coefficient implies that past equilibrium errors play a role in determining the current outcomes (Gujarati, 2004 \& Ibenta, 2012).

Table4: Vector Error Correction Estimates Results

Dependent Variable: GDP

Method: Least Squares, Time: 05:50 
Vector Error Correction Analysis of Foreign Direct Investment and its Effect on the Performance of Nigerian Economy (1990-2018)

Sample: $1990-2018$

Included observations: 29

\begin{tabular}{|l|l|l|l|l|}
\hline Date: $28 / 02 / 2019$ & Coefficient & Std. Error & t-Statistic & Prob. \\
\hline ECM(-1) & -0.782794 & 32.37843 & 3.336474 & -0.000300 \\
D(GDP-1) & 5.486756 & 2.048560 & 0.047553 & 0.000041 \\
D(GDP-2) & 9.625345 & 5.253754 & 1.048572 & 0.000004 \\
C & 2.968574 & 1.947059 & 2.004755 & -0.00050 \\
\hline Ln(FDI) & 6.546742 & 0.756489 & 2.465874 & 0.001340 \\
\hline Ln(EXR) & 8.364846 & 8.769506 & 0.254769 & -0.00028 \\
\hline Ln(INFR) & 7.871435 & 0.476994 & 2.364786 & 0.036452 \\
\hline R-squared & 0.640134 & Mean dependent var & 263.8242 \\
\hline Adjusted R-squared & 0.613985 & \multicolumn{2}{|l|}{ S.D. dependent var } & 142.4637 \\
\hline S.E. of regression & 12.35364 & Akaike info criterion & 15.13259 \\
\hline Sum squared resid & 46583.10 & Schwarz criterion & 11.47569 \\
\hline Log likelihood & -34.13731 & F-statistic & 7.980566 \\
\hline Durbin-Watson stat & 1.805767 & Prob(F-statistic) & 0.000000 \\
\hline
\end{tabular}

Source: Author's computation with the use of E-view 9.1

The results on table 4 show that error-correction coefficient (-0.782794) is statistically significant and has a negative sign, which confirms a necessary condition for the variables to be co-integrated. Hence, there is also a long-run equilibrium impact of foreign direct investments on the performance of Nigerian economy; and, the result confirms that about $78 \%$ short-run adjustment speed from long-run disequilibrium. The coefficient of determination $\left(\mathrm{R}^{2}=0.640134\right)$ indicates that about $64 \%$ of the variations in economic growth can be explained by changes in foreign direct investment variables (FDI, INF and EXR) in Nigeria. This implies that a significant portion of economic growth is explained by changes of foreign direct (FDI) investment variables. The F-Statistics of (7.980566) which is significant at 5\% confirms the effect foreign direct investment on economic growth in Nigeria; for the period 1990-2018. The influence of the explanatory variables on the dependent variable is statistically significant and this is also confirmed by the F-probability which is statistically zero.

\subsection{Test of Hypotheses}

$\mathbf{H o}_{1}$ : There is no significant effect of foreign direct investment on Gross Domestic Product in Nigeria. Decision Criteria, Level of significance $(\alpha)$ :0.05 (5\%), Decision Rule, Reject $\mathrm{H}_{0}$ : If $\mathrm{p}$ - value $<0.05$ and accept $\mathrm{H}_{0}$ if $\mathrm{p}$ - value $>0.05$. The results on table 4 show that foreign direct investment has a tstatistic of 2.465874 with a probability of 0.00134 which is lower than the level of significance of 0.05 , which means, its effect is statistically significant. The null hypothesis is, therefore, rejected. Thus, foreign direct investment has a significant effect on Gross Domestic Product in Nigeria. $\mathbf{H o}_{2}$ : There is no significant effect of exchange rate on Gross Domestic Product in Nigeria. Decision Rule, Reject $\mathrm{H}_{0}$ : If $\mathrm{p}$ - value $<0.05$ and accept $\mathrm{H}_{0}$ if $\mathrm{p}$ - value $>0.05$, The results on table 4 show that exchange rate has a t-statistic of 0.254769 with a probability of -0.00028 which is lower than the level of significance of 0.05 , which means, hence, its effect is negative; but statistically significant. The null hypothesis is, therefore, rejected. Thus, exchange rate is negative; but, has a significant effect on Gross Domestic Product in Nigeria. Ho: There is no significant effect of inflation rate on Gross Domestic Product in Nigeria. Decision Rule, Reject $\mathrm{H}_{0}$ : If $\mathrm{p}$ - value $<0.05$ and accept $\mathrm{H}_{0}$ if $\mathrm{p}$ - value $>$ 0.05 . The results on table 4 show that inflation rate has a t-statistic of 2.364786 with a probability of 0.036452 which is higher than the level of significance of 0.05 , which means, its effect is statistically insignificant. The null hypothesis is, therefore, accepted. Thus, inflation rate has an insignificant effect on Gross Domestic Product in Nigeria

\section{CONCLUSION AND RECOMMENDATIONS}

The study concluded that foreign direct investment has a significantly affected the growth and development of the Nigerian economy. This was evident in the work of Ayanwale (2017), which indicated that there is a significant relationship between non-extractive FDI and economic growth in Nigeria. The study recommends that government policies should be focus on the stability of the economy. Government and policy makers should provide adequate infrastructure and policy 
Vector Error Correction Analysis of Foreign Direct Investment and its Effect on the Performance of Nigerian Economy (1990-2018)

framework that will be conducive for doing business in Nigeria, so as to attract inflow of FDI. There is need for government to be formulating investment policies that will be favorable to local investors in order to complement the inflow of investment from abroad. The government and regulatory authorities in Nigeria should intensify efforts towards providing a conducive and enabling environment, inclusive of more reforms, for the sustained growth in foreign direct investment, given the significant effect of foreign direct investment on the performance of Nigerian economy.CBN and policy makers should adopt vibrant economic policies such as interest rate stability, flexible exchange rate, indigenization and economic diversification that will encourage the banks in financing the communication sector.

\section{REFERENCES}

[1] Andabai, Priye W \& Ikeora, J. J (2018). Fiscal policy and its impact on the private sector growth in Nigeria (1990-2017): International Journal of Economics, Commerce and Management, 6(4), 447-454

[2] Andabai, Priye W \& MaryAnn, N. Igbodika (2018). International trade and performance of the Nigerian economy. Research Journal of Finance and Accounting, 9(4), 166-171.

[3] Akunde, D. (2017). Foreign direct Investment and growth in Nigeria: An empirical investigation. International Journal of Accounting, Economics and Financial Research, 23(16), 327-339

[4] Achide, E. Q (2016). Determinants of foreign direct investment in Nigeria.International Journal of Economics, Finance and Managerial Review, 34(11), 285-289.

[5] Asiedu, E. (2006). Foreign direct investment in Africa: The role of natural resources, market size, government policy, institutions and political instability. The world economy, 29(1), 63-77.

[6] Ayanwale, A. B. (2017). FDI and economic growth: Evidence from Nigeria. AERC Research Paper 165. African Economic Research Consortium, Nairobi.

[7] Basu, A. \& Srinivasan, K. (2017). Foreign direct investment in Africa some case studies.IMF Working Paper wp/02/61.

[8] Jehu, D \& Ogubunka, T (2018). Determinants of foreign direct investment in Nigeria. Global Journal of Economics and Financial Review, 12(6), 249-271.

[9] Khan, A (2017). Foreign direct investment and economic growth: The role of domestic financial sector. International Journal of Marketing and Management Research, 8(5), 323-334.

[10] Legbosi, E. (2017). FDI, financial development and economic growth in Nigeria. Journal of Social Science and Economics, 12(2), 249-271.

[11] Markusen, J.R.\& Venables, A.J. (2018). Foreign direct investment as a catalyst for industrial development. European Journal of Economic and Financial Review, 4(3), 335-356.

[12] Neufus, D. (2018).Impact of foreign direct investment on economic growth in Nigeria. Global Journal of Finance and Accounting Studies. 23(9), 341-351.

[13] Ogbekondu, S. (2018). Foreign direct investment and economic growth in Nigeria: An empirical investigation. EuropeanJournal of Business and Management Review, 34(8), 223-234.

[14] Togbuko, A (2016). Foreign direct investment and exchange rate volatility in Nigeria. International Journal of Economics and Social Sciences. 26(3), 120-129.

[15] Udoh, E. \& Egwaikhide F. O. (2016). Exchange rate volatility, inflation, uncertainty and foreign direct investment in Nigeria. Botswana Journal of Economics, 5(7), 135-145.

[16] Ugwuegbe, S. (2018). Impact of FDI on the Nigerian economy: International evidence. European Journal of Business and Management Research, 5(2), 2222-2839.

Appendix1: Foreign Direct Investment and Economic Growth in Nigeria 1990-2018

\begin{tabular}{|l|l|l|l|l|}
\hline Year & $\begin{array}{l}\text { Foreign Direct Investment } \\
\text { (N' Billion) }\end{array}$ & Inflation Rate (\%) & Exchange Rate (\%) & $\begin{array}{l}\text { GDP at Current Market } \\
\text { Price (\#' Billion) }\end{array}$ \\
\hline 1990 & 45.7 & 20.9 & 48.442 & 472.65 \\
\hline 1991 & 89.5 & 7.7 & 50.962 & 545.67 \\
\hline 1992 & 143.2 & 23.2 & 54.365 & 875.34 \\
\hline 1993 & 165.6 & 39.6 & 58.285 & $1,089.68$ \\
\hline 1994 & 162.8 & 5.5 & 60.826 & $1,399.70$ \\
\hline 1995 & 755.1 & 5.4 & 65.752 & $2,907.36$ \\
\hline 1996 & 562.6 & 10.2 & 83.695 & $4,032.30$ \\
\hline 1997 & 845.7 & 38.3 & 92.693 & $4,189.25$ \\
\hline 1998 & 837.4 & 40.9 & 102.105 & $3,989.45$ \\
\hline
\end{tabular}


Vector Error Correction Analysis of Foreign Direct Investment and its Effect on the Performance of Nigerian Economy (1990-2018)

\begin{tabular}{|l|l|l|l|l|}
\hline \multicolumn{5}{|l}{} \\
\hline 1999 & 862.5 & 7.5 & 111.943 & $4,679.21$ \\
\hline 2000 & 985.0 & 13 & 120.970 & $6,713.57$ \\
\hline 2001 & $1,358.2$ & 44.5 & 129.356 & $6,895.20$ \\
\hline 2002 & $1,512.7$ & 57.2 & 133.500 & $7,795.76$ \\
\hline 2003 & $2,080.2$ & 57 & 131.661 & $9,913.52$ \\
\hline 2004 & $1,987.0$ & 72.8 & 128.651 & $11,411.07$ \\
\hline 2005 & $2,800.9$ & 29.3 & 134.054 & $14,610.88$ \\
\hline 2006 & $3,108.5$ & 8.5 & 132.372 & $18,564.59$ \\
\hline 2007 & $3,912.0$ & 10 & 132.601 & $20,657.32$ \\
\hline 2008 & $5,593.2$ & 6.6 & 128.270 & $24,296.33$ \\
\hline 2009 & $5,480.7$ & 6.9 & 146.680 & $24,794.24$ \\
\hline 2010 & $8,164.0$ & 18.9 & 150.20 & $54,612.26$ \\
\hline 2011 & $10,995.9$ & 12.9 & 156.00 & $62,980.40$ \\
\hline 2012 & $9,766.6$ & 14 & 171.200 & $71,713.94$ \\
\hline 2013 & $9,439.4$ & 10.1 & 180.111 & $80,092.56$ \\
\hline 2014 & $10,538.8$ & 11.5 & 44.527 & $89,043.62$ \\
\hline 2015 & $11,076.1$ & 8.6 & 46.628 & $94,144.96$ \\
\hline 2016 & $11,613.4$ & 6.6 & 32.23 & $92,488.01$ \\
\hline 2017 & $10,356.3$ & 32.4 & 36.12 & $91,253.93$ \\
\hline 2018 & $12,595.6$ & 17.34 & 36.54 & $101,253.934$ \\
\hline
\end{tabular}

Source: Central Bank Nigeria Statistical Bulletin, 2018.

Citation: Andabai Priye Werigbelegha, Mary Ann Nwamaka Igbodika. " Vector Error Correction Analysis of Foreign Direct Investment and its Effect on the Performance of Nigerian Economy (1990-2018)" International Journal of Managerial Studies and Research (IJMSR), vol 7, no. 3, 2019, pp. 22-28. doi: http://dx.doi.org/10.20431/2349-0349.0603003.

Copyright: (c) 2019 Authors. This is an open-access article distributed under the terms of the Creative Commons Attribution License, which permits unrestricted use, distribution, and reproduction in any medium, provided the original author and source are credited. 